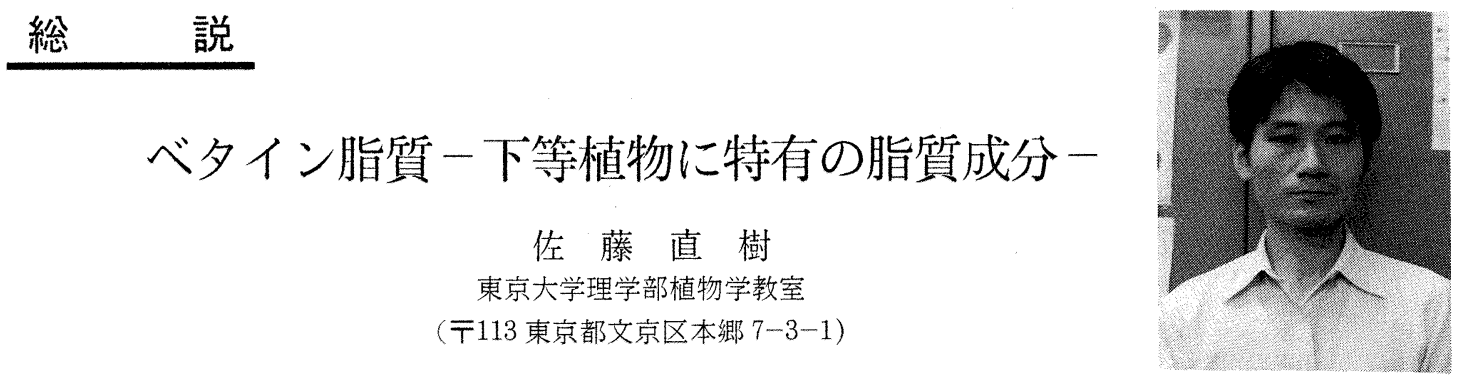

\title{
Betaine Lipids-Lipids Characteristic of Lower Plants
}

\author{
Naoki SATO
}

Department of Botany, Faculty of Science, University of Tokyo

(Hongo, Bunkyo-ku, Tokyo, ₹113)

A recently recognized group of glycerolipids called betaine lipids, which are composed of diacylglycerol and $N$-permethylated hydroxyamino acids, are widely distributed in lower plants and algae as well as in some non-photosynthetic microorganisms. The present state of knowledge of the phylogenetic distribution, the fatty acid composition, the thermal properties, and the biosynthesis of the betaine lipids is reviewed in the perspective of a future sought for their biological roles and activities.

\section{1 緒言}

ベタイン脂質という名称は脂質の専門家にもおうらく はあまりなじみがないものと思われるが，今のところ図 -1 に構造を示す 2 種類の脂質を指している。これらは 通常のグリセロリン脂質やグリセロ糖脂質と同様にジア シルグリセリン (DG) 注) 部分を基本骨格としているが, 極性部分は $N$-メチル化されたヒドロキシアミノ酸であ り, 極性基と DGとがエーテル結合していることが特 徵である。

Dragendorff 試薬陽性でリンを含まない脂質 (Lipid A と Lipid B) が, 黄金色藻 (Chrysophyceae) の一種で ある Ochromonas danica に存在することを, Nichols とAppleby'1) が 1969 年に記載した。1974 年になり Brown と Elovson 2) により, Lipid A はジアシルグリ セリルトリメチルホモセリン (DGTS または DGTH) 之同定された。Lipid B の構造決定は遅れ，ようやく 1990 年になって Eichenbergerのグループ3)により, ジアシルグリセリルヒドロキシメチルトリメチル $\beta$ アラ ニン (DGTA) と決められた。いずれの脂質屯, 陽イオ 注 1) 以下の略語索用いる。

DG, ジアシルグリセリン; DGTA, ジアシルグリセリルヒ

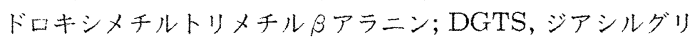
セリルトリメチルホモセリン; DSC, 走査示差熱分析; $\mathrm{ER}$, 工 ンドプラスミックレティキュラム (小胞体) MGDG, モノガ ラクトシルジアシルグリセリン; PA, ホスファチジン酸; PC, ホスファチジルコリン (レシチン).
ンであるトリメチルアンモニウム基と陰イオンであるカ ルボキシル基をもつベタインである。ベタイン脂質に関 する知見はまだ多くはないが，以下に述べるようにこれ らの脂質は下等植物に広く分布し，いくつかの種におい ては主要脂質である。ベタイン脂質は決して特殊な脂質

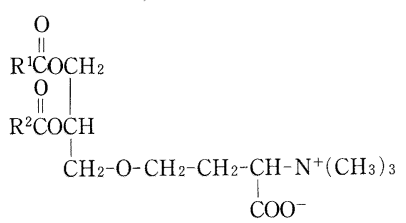

Diacylglyceryl-O-4' ( $N, N, N$-trimethyl $)$ homoserine (DGTS)

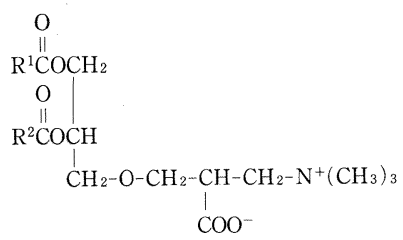

Diacylglycery $1-O-2^{\prime}$ (hydroxymethyl)$(N, N, N$-trimethyl) - $\beta$-alanine (DGTA)

$\mathrm{CH}_{3}-\mathrm{S}-\mathrm{CH}_{2}-\mathrm{CH}_{2}-\mathrm{CH}-\mathrm{NH}_{3}^{+}$ $\mathrm{COO}^{-}$

Methionine

これまでに構造が明らかにされた 2 種類のベタイン脂質と，DGTS の前駆体であるメチオニンの構造を示した。

\section{図一1 ベ夕イン脂質の構造}


ではなく, リン脂質・糖脂質につぐ第 3 のグリセロ脂質 のグループと考えるべきものである。こうした観点から， ベタイン脂質の現状を概観し，広く興味を喚起したい。

\section{2 ベタイン脂彉の植物界における分布}

最初にベタイン脂質が発見されたのは黄金色藻 Ochromonas danica ${ }^{2)}$ からであったが, その後, 緑 藻 Chlamydomonas reinhardtii") からも DGTS が 検出され，さらにDunaliella( ${ }^{5,6)}$ ，Volvox ${ }^{7)}$ な゙゙近緑 の緑藻からも次々上DGTS の存在が確認された。さら に 1983 年には, シダの一種であるホウライシダ (Adiantum capillus-veneris) にも DGTS が含まれること を筆者らが報告した ${ }^{8)}$ 。筆者は緑色植物 (Chlorophyta) について系統的に DGTS の検索を行い,シダ9)・コ ケ $^{10)}$ ・車軸藻 ${ }^{10)}$ ・緑藻 ${ }^{10)}$ の多〈の種に DGTS が含ま れることを明らかにし，DGTS が下等緑色植物にほぼ 普遍的に存在することを示した ${ }^{11)}$ 。この検索の結果を 中心亡して, 筆者 ${ }^{12}$ 及び他の研究者が得た結果 ${ }^{133.14)}$ も 含め, DGTS の生物界における分布を表-1にま之め た。

DGTS の分布をながめてみると，おむしろいことに 気が付く。そ机は DGTS 含量の多い生物種ではホス ファチジルコリン (レシチン, PC) の含量が少ないよ うに思执ることである。最も極端な例はChlamydomonasであり，DGTS を多量に含む一方で，PC は 検出されない ${ }^{10)}$.15)。逆に高等な種子植物では PC だけ があり DGTS は検出さない9)。シダ植物・コケ植物で (両者が共存する ${ }^{9)}$ 10)。緑藻ではクロレラのある種 (Chlorella vulgaris ${ }^{10)}$, C. pyrenoidosa ${ }^{13)}$ ) には DGTS がなく，他の種 (C. fusca $\left.{ }^{16)}\right)$ にはある，上い うような複雑なこともあるが, 多くの緑藻には DGTS と PC が共存する。Chlamydomonas に近縁の Volvocales (Dunaliella, Volvox) や海産の緑藻で市る Ulvophyceae（アナアオサ・ヒトエグサ）ではとくに DGTS の量が多くPC の量が少ないようである。この ようにDGTS と PCの含量が互いに相補的な関係に なっているように見えることは，DGTS と PC とがよ く似た性質をもっているものの，なんらかの理由で進化 の過程で PCが DGTSによって替わったのだというよ うに解釈できる。

上述のように，これまでにDGTS が検出された生物 の大部分は光合成を行う下等植物である。非光合成生物 ではヒトの皮䖉寄生真 菌の一種 ${ }^{14)}$ とアメーバ ${ }^{17)}$ DGTS が検出されている。いまのところ，これらの生 物と上述の光合成生物との関係については㹝っていな い。

DGTA に関しては, 構造決定は遅れたものの, DGTS と同時に検索が進行していたため，その分布状況は既に
かなり明らかにされている（表-1）。最近になって，褐 藻類のいくつかの種に DGTA が多量に含まれることが 判明してきている（荒木繁氏私信及び文献 ${ }^{33}{ }^{18)}$ ) ので, DGTA は有色植物 (Chromophyta) に広く分布する脂 質であるといえそうである。ただ，あ之の生合成の項で 述べるように, DGTA は DGTS を前駆体として作られ ている可能性もあるので，その場合には，DGTAを含 む植物・藻類はすべて DGTS を前駆体として含んでい るはずであるということになる。この点については今後 の研究の進行を待ちたい。

\section{3 ベタイン脂熼の組織・細胞内分布}

ベタイン脂質は, 他のグリセロ脂質と同様に生体膜構 成脂質である。ホウライシダについて筆者が調べたとこ ろでは, 単相世代である原系体・配偶体でも, 複相世 代である胞子体（普通目につく植物体）でも，少量の DGTS が検出された ${ }^{19}$ )。胞子体では葉柄・羽片 (シダ の場合, 茎は地下にあり, 地上にでている部分はすべて 葉である。地面から立ち上がってきているのが葉柄で, 緑色の平たい部分が羽片である。）ともにDGTS を含 んでいた8〉。したがって DGTS は特定の組織・細胞集 団だけにあるものではないようである。

ベタイン脂質を含む植物は上述の上うにすべて下等植 物であるために, 細胞分画がきわめて難しく, ベタイン 脂質が細胞内の特定の膜に存在するかまだはっきりして いない。これまでに得られている断片的な知見によれば, Chlamydomonas 葉緑体のチラコイド膜 ${ }^{20)}$ 之包膜 ${ }^{21)}$, 及び Dunaliella の細胞質膜 ${ }^{22)}$ に DGTS が含まれてい ることがわかっている。

しかし後述 $(4 \cdot 2)$ の上うに, DGTS の C-1 位之 C-2 位の脂肪酸組成のパターンからは, DGTS が細胞質で 作られることが推定されており，まだ脂質組成が調べら れていない ER 等の膜系にも DGTS が含まれているこ とはほぼまちがいない。

DGTA の細胞内分布に関しては, 現在のところ全く 何もわかっていない。

\section{4 ベタイン脂質の分析}

\section{$4 \cdot 1$ 同定法}

ベタイン脂質を検出する最も容易な方法は, 薄層クロ マトグラフィー (TLC) である (図-2)。筆者が開発し た溶媒系 ${ }^{19)}$, 23) (図一2 b) を用いると, DGTS 及び DGTA を含め植物に含まれるすべての主要な脂質クラスを分離 することができる。呈色試薬として Dragendorff 試薬 を用いると, ベタイン脂質は赤橙色に発色する。リン脂 質であるホスファチジルコリン $(\mathrm{PC})$ も同様の発色をす るが，これらを区別するにはリン酸の検出試薬である Dittmer-Lester 試薬を用いればよい。TLCの詳細に 
表-1 ベタイン脂質の生物界における分布

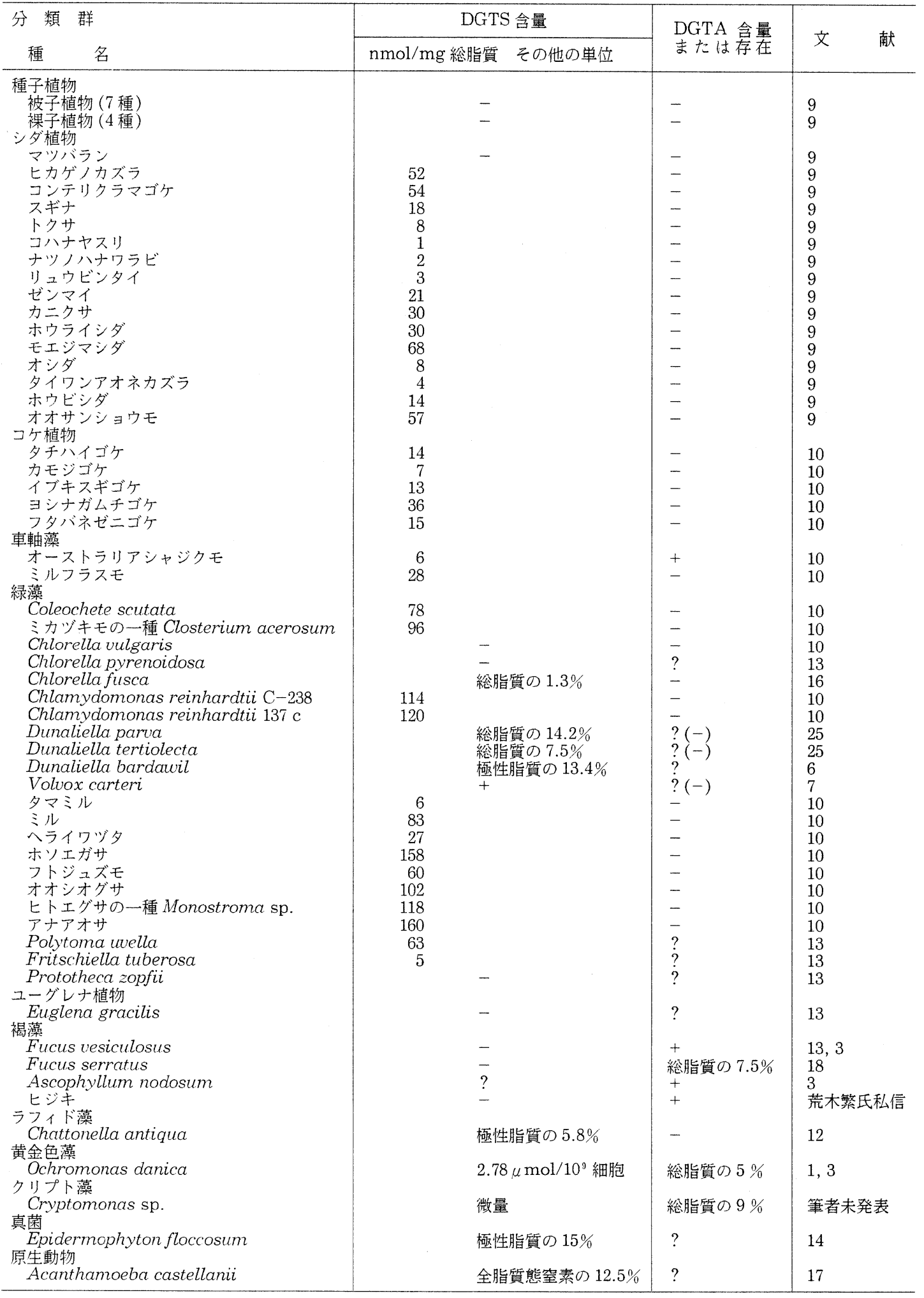




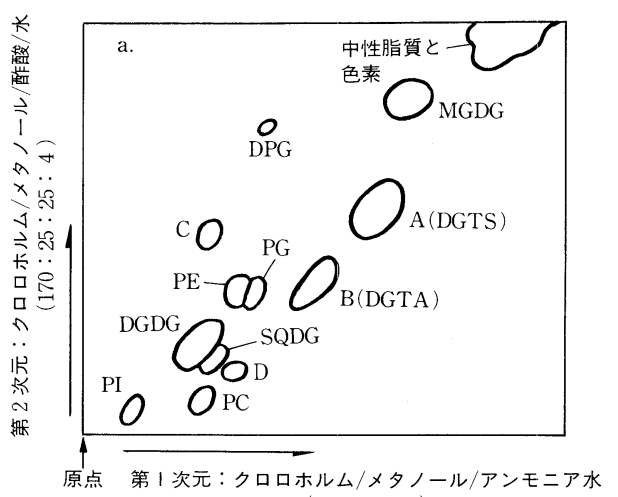

$(65: 25: 4)$

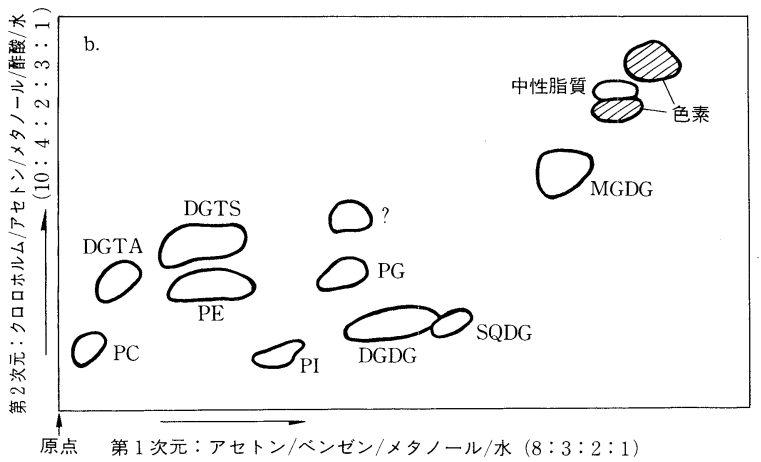

Ochromonas banica の総脂質を 2 次元TLCにより分析したもの。 a は文献24)による。bは筆者の未発表データ。

略号 : MGDG, モノガラクトシルジアシルグリセリン；DGDG， シ ガラクトシルジアシルグリセリン; SQDG, スルホキノボシルジアシ ルグリセリン; $\mathrm{PC}$, ホスファチジルコリン; $\mathrm{PE}$, ホスファチジルエ タノールアミン; $\mathrm{PG}$, ホスファチジルグリセリン; $\mathrm{PI}$, ホスファチジ ルイノシトール; $\mathrm{DPG}$, カルジオリピン。

a では当時未同定であった $\mathrm{A}, \mathrm{B}, \mathrm{C}, \mathrm{D}$ の 4 つの脂質が示されている

が, このうちでAがDGTS,BがDGTAである。

図一2 ベタイン脂質の TLCによる分離

ついては文献 ${ }^{23)}$ を参照されたい。

通常は 2 次元 TLC 上で DGTS P DGTA と紛らわ しい位置に現れる脂質はないが, ベタイン脂質を確認す るには機器分析を行う。NMRによれば特徴的なトリメ チルアンモニウム基及びエーテル結合をはさむ炭素原子 に結合したプロトンが同定でき, DGTS とDGTA との 区別も容易にできる。質量スペクトルでは, DGTSな らばそのまま直接導入 EI 法で分子イオンが検出され る。(M-59)+イオンが強いシグナルを与える。DGTA の場合には，FAB-MS 法によって分子イオンが得られ ている。DGTSのスペタトルデータは文献5)，6)，8)に, DGTAのスペタトルデータは文献 3) に示されている。 なお，注意しなければならないことは, DGTS は比較 的安定であるが, DGTA はクロロホルム溶液中で少量 の酸にさらさ机ると、容易に分解してトリメチルアミン 在生ずることである。こ机が DGTAの構造がなかなか 決めら机なかったこ上の一つの理由でも市忌。ての詳細
は文献 3)に述べられている。

\section{$4 \cdot 2$ 脂肪酸組成之分子種}

DGTS は既に多くの生物種から単離され, 詳細な脂 肪酸組成が調べられている年, 6), 8), 12), 14) 17), 19) 22),25) 29)。 それらのうちから,グリセリンの C-1 と C - 2 に結合し た脂肪酸の組成を表一 2 にまとめた。真菌とアメーバは C-1 位，C-2 位に分けた分析結果がないが，比較のた め脂肪酸組成を示した。特徵的なことは, ほとんどの生 物種において，C-1位には飽和脂肪酸であるパルミチ ン酸がエステル結合しており，C-2 位にはさまざまな 不飽和脂肪酸がエステル結合しているこよである。ただ 例外もあり，最初にDGTS が発見されたOchromonas の場合には, C-1 位にパルミチン酸が少なく, 代わり に $\mathrm{C}_{14}$ のミリスチン酸が含まれている(筆者未発表)。 また，緑藻の一種である Acetabularia（カサノリ）で は C-1 位・C-2 位ともに不飽和脂肪酸が多い ${ }^{29)}$ 。真菌 の DGTS は飽和酸と不飽和酸を含むが, アメーバの DGTS はおむにオレイン酸を含むという点が特徽的で ある。

DGTSの分子種の分析は HPLC を用いることにより 可能になったが，今のところ分析例は少なく，緑藻類の Chlamydomonas ${ }^{15)}$ とDunaliella ${ }^{26)}$ だけである(表 -3)。これを見ると, 飽和酸亡不飽和酸亡の組み合わせ が多いことがわかる。Dunaliellaではミクロソームと 葉緑体に分けて調べられているが, DGTSの分子種組 成に大差はない。

DGTA の脂肪酸組成についてはデータがあまりない が, Ochromonas のものが文献 3) に報告されている。 それによれば, DGTS とDGTA の脂肪酸組成は明らか に異なって抢り, DGTS に多い $\mathrm{C}_{14: 0}$ が DGTA にはほ とんよ゙なく，逆にDGTAには相当な量の $\mathrm{C}_{18: 0}$ や $\mathrm{C}_{22: 3}$ が含まれている。DGTAの C-1 位と C-2 位の脂肪酸 の分布のパターンは, DGTSのものともまたグリセロ 糖脂質やグリセロリン脂質のものともはっきりと違って いた ${ }^{30)}$ 。クリプト藻 Cryptomonas 亡褐藻ヒジキの DGTAの分析結果もあわせて表-4に示す。なお DGTS は少ししか含まれていないので比較はできない。

ここでC-1 位と C-2 位の脂肪酸の分布のパターンを 調べることの意味を説明して扩くのが適当であろう ${ }^{31)}$ 。 高等植物細胞では, 脂質の生合成が葉緑体(プラスチド) と細胞質 $(\mathrm{ER})$ で行わ机る。グリセリンー3ーリン酸の ヒドロキシル基のアシル化を行う酵素（アシルトランス フェラーゼ) はこの両方にあり，それぞれの酵素のアシ 儿基特異性が違っている。このため, 葉緑体でアシル化 が行われてできるホスファチジン酸 (PA) は, C-1 位 に $\mathrm{C}_{18}$ のオレイン酸を $\mathrm{C}-2$ 位には $\mathrm{C}_{16}$ のパルミチン酸 を結合しているが, ERでつくられるPAは, C-1 位に 飽和脂肪酸であるパルミチン酸を, C-2 位に不飽和脂 
表-2 DGTS の脂肪酸組成

\begin{tabular}{|c|c|c|c|c|c|c|c|c|c|c|c|c|c|c|}
\hline \multirow{2}{*}{$\begin{array}{l}\text { 脂肪酸 } \\
\text { (炭素数： } \\
\text { 二重結合数) }\end{array}$} & \multicolumn{2}{|c|}{$\begin{array}{l}\text { Chlamydo- } \\
\text { monas } \\
\text { reinhardtii } 137 \\
\text { c 文献 } 15)\end{array}$} & \multicolumn{2}{|c|}{$\begin{array}{l}\text { Chlorella } \\
\text { fusca } \\
\text { 文献 } 16 \text { ) }\end{array}$} & \multicolumn{2}{|c|}{$\begin{array}{l}\text { ゼニゴケ培 } \\
\text { 養細胞 } \\
\text { 文献 28) }\end{array}$} & \multicolumn{2}{|c|}{$\begin{array}{l}\text { ホウライシ } \\
\text { 葉 } \\
\text { 文献 8) }\end{array}$} & \multicolumn{2}{|c|}{\begin{tabular}{|l|} 
Chattonella \\
antiqua \\
文献 12)
\end{tabular}} & \multicolumn{2}{|c|}{$\begin{array}{l}\text { Ochromonas } \\
\text { danica } \\
\text { 筆者未発表 }\end{array}$} & \multirow{2}{*}{$\begin{array}{l}\text { Epidermophyton } \\
\text { floccosum } \\
\text { 文献 } 14 \text { ) } \\
\text { (DGTS 全体) }\end{array}$} & \multirow{2}{*}{$\begin{array}{l}\text { Acanthamoeba } \\
\text { castellanii } \\
\text { 文献 } 17 \text { ) } \\
\text { (DGTS 全体) }\end{array}$} \\
\hline & $\mathrm{C}-1$ & $\mathrm{C}-2$ & $\mathrm{C}-1$ & $\mathrm{C}-2$ & $C-1$ & $\mathrm{C}-2$ & $\mathrm{C}-1$ & $\mathrm{C}-2$ & $\mathrm{C}-1$ & $\mathrm{C}-2$ & $\mathrm{C}-1$ & $\mathrm{C}-2$ & & \\
\hline $14: 0$ & 0 & 0 & - & - & - & - & - & - & 1 & 0 & 41 & 3 & 0 & 0 \\
\hline $16: 0$ & 58 & 3 & 46 & 5 & 44 & 2 & 44 & 0 & 48 & 1 & 4 & - & 37 & 7 \\
\hline $16: 1$ & 2 & 7 & 5 & 16 & 2 & 2 & - & - & 0 & 0 & - & - & 3 & 0 \\
\hline その他の $\mathrm{C}_{16}$ & 0 & 4 & 1 & 8 & 0 & 0 & 0 & 0 & 0 & 0 & 0 & 0 & 0 & 0 \\
\hline $18: 0$ & 2 & 0 & 1 & 1 & 0 & 0 & 1 & 0 & 0 & 0 & 1 & 0 & 3 & 6 \\
\hline $18: 1$ & 7 & 2 & 36 & 37 & 0 & 21 & 1 & 4 & 0 & 0 & 1 & 12 & 8 & 87 \\
\hline $18: 2$ & 17 & 11 & 5 & 13 & 0 & 11 & 0 & 20 & 0 & 0 & 1 & 16 & 46 & 0 \\
\hline $18: 3(9,12,15)$ & 7 & 3 & 3 & 12 & 1 & 6 & 0 & 21 & 0 & 0 & 0 & 1 & 0 & 0 \\
\hline その他の $18: 3$ & 5 & 59 & - & - & - & - & 0 & 1 & 0 & 0 & 0 & 4 & 0 & 0 \\
\hline $18: 4$ & 1 & 9 & 0 & 0 & 0 & 1 & - & - & 0 & 0 & - & - & 0 & 0 \\
\hline $20: 3$ & 0 & 0 & - & - & - & - & - & - & 0 & 0 & 0 & 8 & 0 & 0 \\
\hline $20: 4$ & 0 & 0 & - & - & 1 & 1 & 1 & 3 & 1 & 10 & 1 & 2 & 0 & 0 \\
\hline $20: 5$ & 0 & 0 & - & - & 0 & 0 & - & - & 0 & 35 & - & - & 0 & 0 \\
\hline その他の $\mathrm{C}_{20}$ & 0 & 0 & - & - & - & - & 0 & 0 & 0 & 0 & - & - & 0 & 0 \\
\hline $\mathrm{C}_{22}$ & 0 & 0 & - & - & - & - & 0 & 0 & 0 & 0 & 0 & 2 & 0 & 0 \\
\hline その他 & 0 & 0 & 3 & 8 & 2 & 6 & 3 & 1 & 0 & 0 & 1 & 2 & 3 & 0 \\
\hline 計 & 100 & 100 & 100 & 100 & 50 & 50 & 50 & 50 & 50 & 50 & 50 & 50 & 100 & 100 \\
\hline
\end{tabular}

「その他」には，上にリストされていない脂肪酸及び表中に含量が横線（一) で示されている脂肪酸が含まれる。

6 種の植物については, DGTS のグリセリン部分の C -1 位と C -2 位に分けて脂肪酸の組成を調べた值を示し, 右側の 2 種の生物については DGTS 全体の脂肪酸組成を示した。適宜, 小数点以下の数字を四捨五入してある。文献によりC-1 位とC-2 位のそ机ぞ机について脂肪酸量の合計を $100 \%$ としている場合と，そ机ぞ机を $50 \%$ としてDGTS 全体で $100 \%$ となるようにしている場合とがあるが，出典の通りに引用した。

肪酸であるオレイン酸・リノール酸などを結合してい る。すべてのグリセロ脂質は PA またはその脱リン酸 化によってつくられるジアシルグリセリン (DG) を前 駆体として作ら机ると考元られているので，それぞれの 脂質クラスの $\mathrm{C}-1$ 位と $\mathrm{C}-2$ 位の脂肪酸を調べることに よって, その脂質クラスが細胞のどこで作られたのかを 推定できるはずであるという論理になる。なおその際に は, PAに結合したときの脂肪酸がそのままあるのでは なく, 不飽和化をうけて二重結合の数の多い不飽和脂肪 酸に変換されていくことを考慮する必要がある。また $\mathrm{ER} の \mathrm{PC}$ では脂肪酸の脱離によるリゾ脂質の生成と, リゾ脂質のアシル化によるPC の生成もあるので事情は やや複雑になる。このような立場から DGTS の脂肪酸 組成を見るならば, DGTS は典型的な ER 合成型の脂 質である。しかし，DGTS を含むような下等な植物に ついて, 脂質合成に関する上記の理論があてはまるのか 否かについてはまだ明らかではない。DGTAの脂肪酸 パターンに至っては，今のところ説明することができな い。下等植物における脂質の合成のしくみは, 高等植物 のものよりもかなり複雑なようである。

\section{5 ベタイン脂質の物理化学的性筫}

第 2 項にも述べたように，いろいろな植物種を調べて みるとDGTS と PC の含量が互いに相補的な関係に なっているように見える。このことは DGTS と PC と がよく似た性質をもち, 細胞内においても類似の役割を 果たしている可能性を示唆している。DGTS と PC と はともに両性イオン脂質であるという共通点があるもの の, 実際に DGTS と PC との物理化学的な性質を比較 した研究はまだ少ない。最近筆者らは, DGTSのいく つかの飽和分子種についてその液㫛相一固相間の相転移 温度を示差熱分析 (DSC) 法及びトランスパリナリン酸 をプローブとした偏蛍光解消法により測定した ${ }^{32)}$ 。1パルミトイルー2-ステアロイル分子種の相転移温度は $53^{\circ} \mathrm{C}, 1,2-$ ジステアロイル分子種の相転移温度は $59^{\circ} \mathrm{C}$ であった。これらの值は対応する PC 分子種の相転移温 度 $\left(47^{\circ} \mathrm{C}\right.$ と $\left.54^{\circ} \mathrm{C}\right)$ に比べてそれぞれ $6^{\circ} \mathrm{C}$ 及び $5^{\circ} \mathrm{C}$ だけ 高かった。この結果は, DGTS が PC と類似の相転移 を起こすものの, DGTS 分子間の相互作用の方が PC 分子間相互作用よりも強いために, 相転移を起こす温度 が少し高くなることを示している。今のところ, 生体内 に存在する不飽和分子種についての測定は行わ机ていな 
表-3 DGTSの分子種組成

\begin{tabular}{c|c|cc}
\hline \multirow{2}{*}{$\begin{array}{c}\text { 分子種 } \\
\text { C-1/C-2 }\end{array}$} & $\begin{array}{c}\text { Chlamydomonas } \\
\text { reinhardtii } \\
\text { (文献 15) } \\
\text { 細 }\end{array}$ & \multicolumn{2}{|c}{$\begin{array}{c}\text { Dunaliella salina } \\
\text { (支献 26) }\end{array}$} \\
\cline { 3 - 4 } $16: 0 / 14: 2$ & 0 & 2 & 0 \\
$16: 0 / 18: 2$ & 8 & 46 & 43 \\
$16: 0 / 18: 3$ & 28 & 34 & 32 \\
$16: 0 / 18: 4$ & 15 & 0 & 0 \\
$18: 0 / 18: 3$ & - & 1 & 2 \\
$18: 1 / 18: 2$ & 3 & 8 & 11 \\
$18: 1 / 18: 3$ & 6 & 0 & 0 \\
$18: 1 / 18: 4$ & 4 & 0 & 0 \\
$18: 2 / 18: 2$ & 3 & 0 & 0 \\
$18: 2 / 18: 3$ & 12 & 5 & 9 \\
$18: 3 / 18: 1$ & 5 & 0 & 0 \\
$18: 3 / 18: 3$ & 8 & 4 & 3 \\
$18: 3 / 18: 4$ & 3 & 0 & 0 \\
その他 & 5 & 0 & 0 \\
\hline
\end{tabular}

これら2種の緑藻は互いにきわめて近縁の種ではある が、含ま机る脂肪酸の種類に微妙な違いがあり．両者の DGTS 分子種の組成をこのような一つの表にまとめる ことには無理がある。18:3 として示したものは, Dunaliella では $18: 3(9,12,15)$ ( $\alpha$-リノレン酸) と $18: 3$ $(6,9,12)$ ( $\gamma$-リノレン酸) であり, Chlamydomonas では $18: 3(9,12,15)$ 之珍しい $18: 3(5,9,12)$ であ る。表を作る過程で適宜こ扎らの異性体をあわせて表示 した。詳細は原報を参照されたい。

いので, DGTS のすべての分子種が対応する PCの分 子種よりも高い相転移温度を示すという証明はさ机てい ない。

なお，熱的な性質以外の DGTS の物理化学的性質 については残念ながらまだ何も知られていない。また DGTA の物理化学的性質は, DGTA の化学的不安定性 (4・1参照) のためもあって, まだ詳しく調べられてい ない。

\section{6 ベタイン脂筫の生合成}

\section{$6 \cdot 1$ 極性基の生合成}

ベタイン脂質の生合成に関して最も重要な問題は，そ の特異な極性基の由来とエーテル結合の形成機構であ る。当初は DGTS の極性基をラベルするためにホモセ リンが試されたが, ホモセリンからのラベルは各種の物 質に取り込まれ，DGTS だけに特異的に取り込まれる ということはなかった(W. Eichenberger 私信)。その 後、筆者はChlamydomonas 細胞を用いて DGTS の 生合成に抢ける極性基の前駆体の唡索を行った ${ }^{333} 。$ 種々の位置がラベルされたメチオニンを用いて, DGTS
表-4 DGTA の脂肪酸組成

\begin{tabular}{c|c|c|c}
\hline $\begin{array}{c}\text { 脂肪酸 } \\
\text { (炭素数 : } \\
\text { 二重結合数) }\end{array}$ & $\begin{array}{l}\text { Ochromo- } \\
\text { nas } \\
\text { danica } \\
\text { (文献 } 3)\end{array}$ & $\begin{array}{l}\text { Cryptomonas } \\
\text { sp. } \\
\text { (筆者未発表) }\end{array}$ & $\begin{array}{l}\text { ヒ } \\
\text { (荒木繁氏私信) }\end{array}$ \\
\hline $14: 0$ & 1 & 1 & 6 \\
$16: 0$ & 3 & 16 & 26 \\
$16: 1$ & - & 2 & 2 \\
$18: 0$ & 15 & 6 & 1 \\
$18: 1$ & 5 & 12 & 3 \\
$18: 2$ & 4 & 2 & 9 \\
$18: 3$ & - & 10 & 4 \\
$20: 2$ & 6 & 0 & 1 \\
$20: 3$ & 4 & 0 & 0 \\
$20: 4$ & 13 & 2 & 37 \\
$20: 5$ & - & 17 & 8 \\
$22: 4$ & 3 & 16 & 0 \\
$22: 5$ & 43 & 2 & 0 \\
$22: 6$ & - & 5 & 0 \\
その他 & 4 & 5 & 3 \\
\hline
\end{tabular}

への取り込みを測定すると, $\left[1-{ }^{14} \mathrm{C}\right]$ メチオニン及び $\left[3,4-{ }^{14} \mathrm{C}\right] \times$ ×オニンからのラベルは, DGTS に特異 的に取り込まれ（図一 $-3 \mathbf{a}, \mathbf{b})$, 取り込ま机た放射能は極 性基部分(トリメチルホモセリン部分)に局在していた。 このことは, メチオニンの $\mathrm{C}_{4}$ の炭素骨格部分が DGTS の極性基の $\mathrm{C}_{4}$ の骨格の前駆体であることを示してい る。

興味深いことに, メチル基ラベルのメチオニンを用い るとやはり特異的にDGTS の極性基部分に取り込まれ た（図ー3 c)。したがって，メチオニンの $S$ 一メチル基 が DGTS の $N$-メチル基の前駆体であることになり， メチオニンはそのメチル基と $\mathrm{C}_{4}$ 骨格の両方を DGTS の前駆体として提供するという，二重の意味での前駆体 であることが判明した ${ }^{33)}$ ○チオニンが DGTS の前駆 体であることは，コケの一種であるMarchantia（ゼ二 ゴケ）の培養細胞でも確かめられた ${ }^{28)}$ 。

DGTA の生合成については，まだあまりよくわかっ ていないが, DGTS がその前駆体となっている可能性 がある。クリプト藻の一種であるCryptomonas の細 胞には, DGTA が PC な゙゙のリン脂質及びガラクト脂 質などとともに含まれているが，通常の 2 次元 TLC の 分析ではDGTS は検出されない。ところが,この細胞に ラベルしたメチオニンを与えると, TLC 上で DGTSと 思わ彷る位置に放射能のスポットが現れ，このスポット の放射能はすぐに定常レベルになった。DGTAへは多 量の放射能が継続的に取り込ま机ていった（図一4）。こ 机は DGTS が DGTA の前駆体である可能性を示唆し ているが(筆者未発表)，さらに詳しい解析が必要であ 


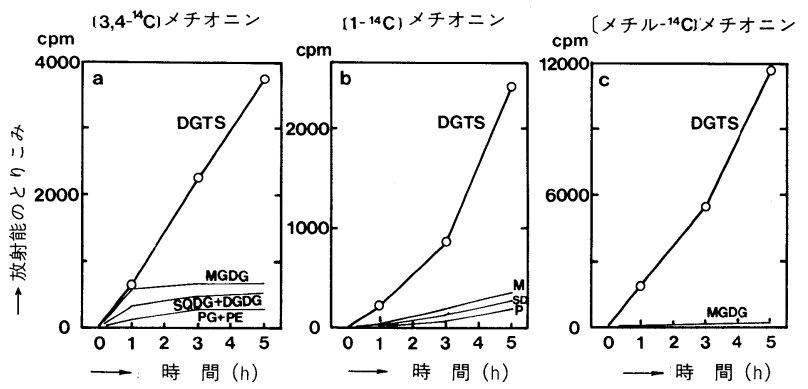

略号：MGDG（または M)：モノガラクトシルジアシ ルグリセリン

DGDG（またはD）：ジガラクトシルジアシルグ リセリン

$\mathrm{SQDG}$ (または $\mathrm{S})$ : スルホキシノボシルジアシ ルグリセリン

$\mathrm{PG}:$ ホスファチジルグリセリン

$\mathrm{PE}$ : ホスファチジルエタノールアミン

$\mathrm{P}$ は $\mathrm{PG}+\mathrm{PE}$

Chlamydomonas 細胞を ${ }^{14} \mathrm{C}$ ラベルしたメチオニンし 亡もに通常の培湌条件でインキューベートした後, 脂質 を抽出して 2 次元 TLCにより分画し, 各脂質への放射 能の取り込みを測定した ${ }^{33)}$ 。

図ー3 メチオニンからの DGTS の生合成

る。もし DGTS が DGTAに変換されるのであるとす ると, カルボキシル基が隣の炭素に移動することになる のか，それとも一度カルボキシル基がはずれたのちに， 別のカルボキシル基が入るのか, など興味の持たれると ころである。

\section{$6 \cdot 2$ アシル基部分の代謝・不飽和化}

植物細胞に ${ }^{14} \mathrm{C}$ でラベルした脂肪酸を与えると速や かに細胞に取り込まれ，脂質に組み込まれる。このとき PC が主にラベルされるのが普通である。これに対して， PC を含まずにDGTSをもつChlamydomonasでは， ラベルされた脂肪酸が効率よく DGTSに取り込まれ る ${ }^{34)}$ 。オレイン酸 $\left(\mathrm{C}_{18: 1}\right)$ が DGTSに取り込まれると, その後のインキュベーションの間に不飽和化を受けて，

リノ一ル酸 $\left(\mathrm{C}_{18: 2}\right)$ に变換され, 一部はさらに不飽和化 されてリノレン酸の異性体（ $\left.\Delta^{5,9,12}-\mathrm{C}_{18: 3}\right)$ になる〔文 献 34 では $\gamma$ リノレン酸 $\left(\Delta^{6,9.12}-\mathrm{C}_{18: 3}\right)$ となっている が, その後の研究に上り二重結合の位置が訂正さ机 た ${ }^{15) \cdot 35) 。 し た か ゙ っ て ~ C h l a m y d o m o n a s に は ~} \Delta^{5,9.12}$ と $\Delta^{9.12 .15}$ の 2 種類の $\mathrm{C}_{18: 3}$ 脂肪酸があることになる】。こ の変換の詳細な解析から, オレイン酸からリノール酸等 への不飽和化では DGTSに結合した脂肪酸が不飽和化

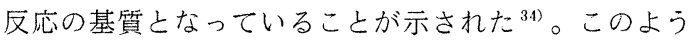
な脂質結合型の脂肪酸不飽和化は, 高等植物 ${ }^{31)}$ の $\mathrm{PC}$ や MGDG（モ)ガラクトシルジアシルグリセリン）及 びラン藻 (シアノバクテリア) の $\mathrm{MGDG}^{36)}$ で起こって

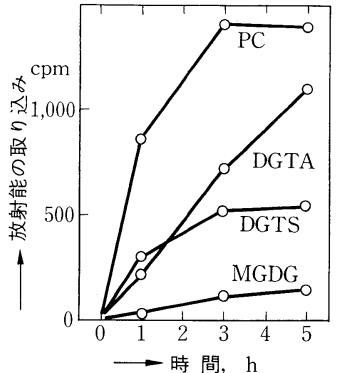

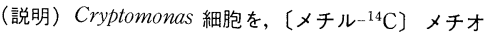
ニンとともに通常の培養条件でインキュベー トした後, 脂質を抽出して 2 次元TLCにより 分画し, 各脂質への放射能の取り込みを測定 した。筆者未発表。

略号：PC, ホスファチジルコリン; MGDG, モ ノガラクトシルジアシルグリセリン。

図-4 CryptomonasにおけるDGTA の合成

いるこよが知られているが，PCをもたない Chlamydomonas では DGTS が代わりに不飽和化の基質上 なっていると思われ，ここでも PC亡DGTS との類似 性が示されたことになる。

細胞周期における脂質合成については Chlamydomomas で調べられている ${ }^{37)} 。 12 \mathrm{~h}$ 明期 $-12 \mathrm{~h}$ 暗期の 周期で同調培養した細胞を一定時間ごとにとりだして $\left[{ }^{14} \mathrm{C}\right]$ 酢酸を与えて，脂質への取り込みを测定したとこ ろ，明期に脂質合成が盛んであり，特に明期開始後 6 時 間目で最も脂質合成活性が高かった。これはDGTSな ど主なグリセロ脂質についてもほぼ同様であった。した がって, DGTS はその他の脂質と同調して作られてい ると思われる。

\section{7 ベタイン脂浐の化学的合成}

DGTSを化学合成する試みの一環として，その類似 体であるジプロピオニルグリセリルトリメチルセリンが

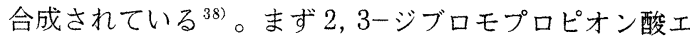

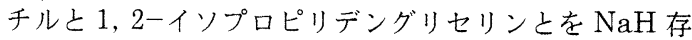
在下で結合させて，エーテル結合が作られた。残った臭 素原子をトリメチルアミンにより置換したのち, 保護基 のアセトンをはずし，プロピオン酸無水物によりアシル 化して, 目的の産物を得た。2,3-ジブロモプロピオン 酸エチルの代わりに2,4-ジブロモ酪酸エチルを用いれ ば, DGTS が作机るはずであるが，実際にはグリセリ ルエーテルができずにシクロプロパン化合物ができてし まったよのことである。

したがって，まだ DGTS の完全な合成はなされてい ないが，天然の DGTS を原料として脂肪酸を改変する ことが行わ机ている。不飽和脂肪酸を飽和化するために は,パラジウム黒なじを触媒しした水素添加が行われる。 
脂肪酸をはずすには，アルカリを用い，アシル化するに は酸クロリドが用いられる゙)。

\section{8 ベタイン脂質の生物活性}

ベタイン脂質は海藻類やシダ類などわれわれ日本人が 食用としている植物に含まれており，その人体への影響 ・生理作用には興味が持たれるところである。食用の海 藻としてDGTS を含むものはアオノリと呼ば机る緑藻 ぐらいのもので，あまり多くはない。DGTAを含むも のには褐澡類のヒジキがある。紅藻類である普通のノリ (アサクサノリ・スサビノリ)や, 褐藻類でもワカメ（コ ンブは不明)にはベタイン脂質は含ま机ていない。その ほか山菜として食用にされるワラビ・ゼンマイ等のシダ 類にはDGTS が含まれている（表一1）。

ベタイン脂質中のエーテル結合は消化作用によって分 解さ机るとは思打机ないので, ベタイン脂質の脱アシル 化物がそのまま人体に吸収されている可能性がある。阿 部・金田 $(1975)^{39)}$ は, アオノリの近縁種 Monostroma nitidum から DGTS の脱アシル化物を ulvaline とし て単離したが, このものをラットに与えたところ,わず かながらコレステロールを減少させる (hypocholesterolemic) 作用があることを見いだした。

また海には海藻をえさとする小動物がいるが, アメフ ラシやアワビなどの藻食性巻貝類に対して, アナアオサ などに含まれるDGTS が摂じ(餌)刺激物質となること が示されている ${ }^{40)}$ 。

ベタイン脂質の生理作用として知られていることはこ の程度であり,いまのよころ, 少なくとも人体に対して 著しい害作用も健康增進作用も報告されていない上うで ある。

\section{9 おわりに}

本稿ではベタイン脂質であるDGTS と DGTA に関 して知られていることを網ら(羅)的に紹介した。ベタイ ン脂質に関する報文は引用文献としてあげたものでほぼ つくされているはずである。それほどにベタイン脂質に 関する研究は少ないのが実状であるが，はじめにも述べ たように，ベタイン脂質をグリセロ脂質の中でグリセロ リン脂質とグリセロ糖脂質に次ぐ第 3 のグループを形作 る重要な脂質群であると位置づけることが無理のないこ とであるということは, 理解される段階にきているもの と思わ机る。

海産の藻類には多くの種類のベタイン化合物が含まれ ており, 天然物化学の立場からはきわめて多くの研究が なさ机ている。今そのすべてについて言及することはで きないが, 緑藻と紅藻におけるべタインまたは第四級ア ンモニウム化合物の分布を調べた文献11 をあげておく。 先に述べた ulvaline を除けば,これまでに知られてい
るベタイン類とベタイン脂質との間に直接の関係はなさ そうであるが，生体内にはきわめて多種多彩な第四級ア ンモニウム化合物があることを考えるとき，それらに共 通した意義を見いだすことができるのかもしれない。

前項で食品中のベタイン脂質が人体に及ぼす影響がま だよくわかっていないことを述べた。植物科学を専門之 する筆者の能くするところではないが, 専門の方が調べ てくださることを期待したい。

[平成 2 年 (1990 年) 8 月 21 日受理]

\section{文献}

1)' B.W. Nichols, R.S. Appleby, Phytochemistry, 8, 1907 (1969)

2) A.E. Brown, J. Elovson, Biochemistry, 13, 3476 (1974)

3) G. Vogel, M. Woznica, H. Gfeller, C. Muller, A.A. Stampfli, T.A. Jenny, W. Eichenberger, Chem. Phys. Lipids, 52, 99 (1990)

4) W. Eichenberger, A. Boschetti, FEBS Lett., 88, 201 (1978)

5) R.W. Evans, M. Kates, G.W. Wood, Chem. Phys. Lipids, 31, 331 (1982)

6) A. Fried, A. Tietz, A. Ben-Amotz, W. Eichenberger, Biochim. Biophys. Acta, 713, 419 (1982)

7) K.R. Moseley, G.A. Thompson, Jr., Plant Physiol., 65, 260 (1980)

8) N. Sato, M. Furuya, Plant Cell Physiol., 24, 1113 (1983)

9) N. Sato, M. Furuya, Phytochemistry, 23, 1625 (1984)

10) N. Sato, M. Furuya, Plant Sci., 38, 81 (1985)

11) N. Sato, M. Furuya, "Structure, Function and Metabolism of Plant Lipids" (P.A. Siegenthaler, W. Eichenberger, eds.), Elsevier Science Publishers, B.V. Amsterdam, (1985) p.171

12) N. Sato, Y. Nemoto, M. Furuya, Plant Physiol. Biochem., 26, 93 (1988)

13) W. Eichenberger, Plant Sci., 24, 91 (1982)

14) T. Yamada, Y. Nozawa, Biochim. Biophys. Acta, 574, 433 (1979)

15) C. Giroud, A. Gerber, W. Eichenberger, Plant Cell Physiol., 29, 587 (1988)

16) N. Weber, D. Bergenthal, C.K. Kokate, H.K. Mangold, J. Lipid Mediators, 1, 37 (1989)

17) S.T. Furlong, J.A. Leary, C.E. Costello, E.A. Davidowicz, J. Lipid Res., 27, 1182 (1986)

18) K.L. Smith, J.L. Harwood, Phytochemistry, 23, 2469 (1984)

19) N. Sato, M. Furuya, Physiol. Plant., 62, 139 (1984)

20) D.R. Janero, R. Barrnett, J. Lipid Res., 23, 307 (1982)

21) L. Mendiola-Morgenthaler, W. Eichenberger, A. Boschetti, Plant Sci., 41, 97 (1985)

22) M. Sheffer, A. Fried, H.E. Gottlieb, A. Tietz, 
M. Avron, Biochim. Biophys. Acta, 857, 165 (1986)

23）佐藤直樹, 奥山治美, 蛋白質 - 核酸 - 酵素別冊 30 巻, (1987) p. 163

24) B.W. Nichols, "Phytochemical Phylogeny" (J.B. Harborne, ed.) Academic Press, London, (1970) p. 105

25) R.W. Evans, M. Kates, M. Ginzburg,B. -Z. Ginzburg, Biochim. Biophys. Actc, 712, 186 (1982)

26) H.A. Norman, G.A. Thompson, Jr., Plant Sci., 42, 83 (1985)

27) D.R. Janero, R. Barrnett, Phytochemistry, 21, 47 (1982)

28) N. Sato, K. Kato, Plant Sci., 55, 21 (1988)

29) W. Eichenberger, A. Gerber, "The Metabolism, Structure and Function of Plant Lipids" (P.K. Stumpf, J.B. Mudd, W.D. Nes, eds.) Plenum Press, New York (1986) p.637

30) W. Eichenberger, The 24 th NIBB Conference "Membrane Biogenesis and Temperature Acclimation of Plants" Okazaki, Jan. 15-17 (1990) p.
39

31) P.G. Roughan, C.R. Slack, Annu. Rev. Plant Physiol., 33, 97 (1982)

32) N. Sato, N. Murata, Biochim. Biophys. Acta, "Transition of lipid phase in aqueous dispersions of diacylglyceryltrimethylhomoserine” 印刷中

33) N. Sato, Plant Physiol., 86, 931 (1988)

34) P. Schlapfer, W. Eichenberger, Plant Sci. Lett., 32, 243 (1983)

35) N. Sato, Plant Sci., 61, 17 (1989)

36) N. Sato, Y. Seyama, N. Murata, Plant Cell Physiol., 27, 819 (1986)

37) D.R. Janero, R. Barrnett, J. Cell Biol., 91, 126 (1981)

38) M.K. Choudhury, W. Eichenberger, Chem. Phys. Lipids, 36, 351 (1985)

39) S. Abe, T. Kaneda, Bull. Japan. Soc. Sci. Fish., 41, 567 (1975)

40) K. Sakata, M. Tsuge, Y. Kamiya, K. Ina, Agric. Biol. Chem., 49, 1905 (1985)

41) G. Blunden, S.M. Gordon, W.F.H. Mclean, M.D. Guiry, Bot. Mar., 25, 563 (1982) 